\title{
Evaluation of School Buildings in Basrah using Geographic Information Systems and Artificial Neural Networks
}

\author{
Khadijah A. Hussein \\ University of Basra \\ College of Arts \\ Basrah, Iraq
}

\author{
Kareem Radhi Hussein \\ University of Basra \\ College of sciences \\ Basrah, Iraq
}

\author{
Lamia' Sabah Shihab \\ University of Basra \\ College of sciences \\ Basrah, Iraq
}

\begin{abstract}
Education services are a basic requirement in any community for they have the responsibility to develop and promote communities. They are one cornerstone of life and a strong pillar of civilization. The current study aims to evaluate the locations of public school buildings in Basra City ( at the south Iraq) using the integration of Geographic Information Systems (GIS) and Artificial Neural Networks(ANN), thus adopting a set of planning standards. Thus classified school buildings into classes ranged from (3-5) depending on the degree of conformity of every study stage where the percentages differed $(0.69 \%$ rejected, $52.09 \%$ unsuitable, $36.36 \%$ acceptable, and $9.99 \%$ suitable and 1.74 good. This could be attributed to the random selection and bad planning of these locations which, in turn, shows that there is a failure in the plans of developing education services in the city. That is why the study recommends adopting modern technologies to contribute effectively to raising the efficiency of urban planning processes and improve the performance of the planning process in and decision-making to provide the best community services for residents of Basra, including education.
\end{abstract}

\section{General Terms}

Back propagation Algorithm, spatial analysis, modelling, evaluation Natural Breaks, classification

\section{Keywords}

ANN, GIS, Model, Geo_DB, location, data set.

\section{INTRODUCTION $[1,2]$}

Planners describe the current era as the era of information, revolution and great technologies. The implications of such progress include various planning processes such as computer design, information systems, databases and remote sensing techniques, through which data can be collected, transferred and analyzed for many areas that require speed and accuracy when taking decisions. In view of the enormous urban development and the resulting problems such as the random increase in growth rates and lack of natural resources, as well as the random urban expansion, these and other reasons led to move from the work with tools and traditional analytical methods to the adoption of modern techniques at all stages of the planning process. Hence, GIS technologies and artificial intelligence, such as neural networks, are among the most important technologies adopted in the field of land use planning for their ability to represent real spatial data and computerized processing on spatial databases, which helps planners and decision makers to achieve the optimal planning of the city in line with future requirements. The importance of the study lies in the use of spatial modeling of school buildings locationsandtheir integration with neural network technology for the purpose of evaluation and recognition of the level of efficiency of use. More specifically, it aims to evaluate the locations of the school buildings in Basra by adopting the integrated approach between GIS and Neural

\section{STUDY AREA [3, 4]}

The city of Basra is located at the south of Iraq along the

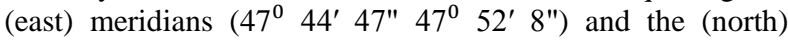

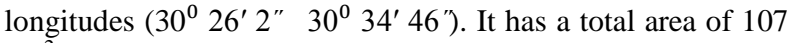
$\mathrm{km}^{2}$. Its population is (1377104) according to the estimates of (2016). It is divided into (55) districts distributed among six administrative sectors. Figure (1) shows its residential quarters.

\section{PLANNING STANDARDS $[5,6,7]$}

The process of urban planning for the uses of the educational land is subject to a set of standards, so it has been adopted for the purpose of matching and evaluation. Four planning standards were chosen to evaluate the location of government school buildings in Basra. These are:

1. Distance to Main Street: This is the distance between the school and the main street. This distance varies according to the educational stages (kindergarten, primary, intermediate, high school). For example, primary schools need to move away from the main street by no less than $150 \mathrm{~m}$ while this distance is lower in intermediate schools where it reaches $100 \mathrm{~m}$ and so for the rest of the educational stages.

2. Area: This refers to the area allocated for each building. It varies according to study stages. For example, intermediate schools need an area of no less than (10000) $\mathrm{m}^{2}$ and the primary schools need to have areas no less than (5000) $\mathrm{m}^{2}$ and so for the rest of the other stages.

3. Distance to Risk: Petrol stations were regarded as dangerous places in the study area. School locations should be far from them in certain areas for the safety of pupils.

4. Distance between Schools: All schools are subject to distribution system that adopts certain distances between one school and another for the same school stages. For example, the planning standard sets the distance of $(500 \mathrm{~m})$ among primary schools and $(750 \mathrm{~m})$ among intermediate schools and so on for the rest of the schools. Table (1) illustrates these standards. 


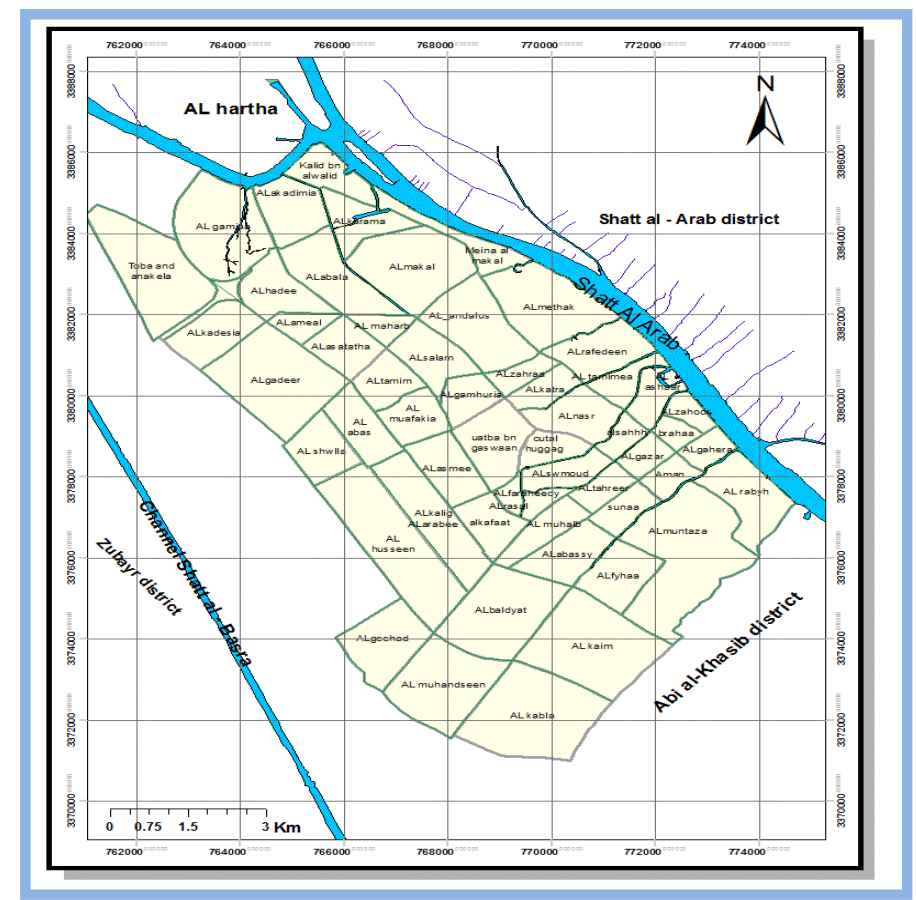

Figure (1) : Residential Quarters in Basr

Table 1. Approved Local Planning Standards adopted in the Present Study[1,10]

\begin{tabular}{|c|c|c|c|c|c|}
\hline \multirow[b]{2}{*}{ No } & \multirow[b]{2}{*}{ 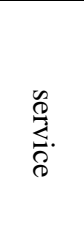 } & \multicolumn{4}{|c|}{ Local standard } \\
\hline & & $\begin{array}{c}\text { Distan } \\
\text { ce to } \\
\text { main } \\
\text { street/ } \\
\text { m }\end{array}$ & $\begin{array}{l}\text { Distance } \\
\text { between } \\
\text { schools/m }\end{array}$ & $\begin{array}{l}\text { Distance } \\
\text { to petrol } \\
\text { station } / \mathrm{m}\end{array}$ & Area $/ \mathrm{m}^{2}$ \\
\hline 1 & 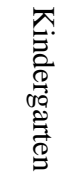 & 150 & 500 & 100 & $\begin{array}{l}3000- \\
3500\end{array}$ \\
\hline 2 & 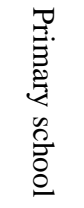 & 150 & 500 & 100 & $\begin{array}{c}5000- \\
7000\end{array}$ \\
\hline 3 & 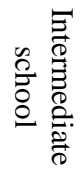 & 100 & 750 & 100 & $\begin{array}{l}8000- \\
10000\end{array}$ \\
\hline 4 & 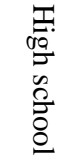 & 100 & 1500 & 100 & $\begin{array}{c}10000- \\
15000\end{array}$ \\
\hline
\end{tabular}

\section{GEOGRAPHIC INFORMATION SYSTEMS (GIS) $[8,9,10,11]$}

Geographic Information System (GIS) is defined as a computerized technology that is highly capable of building analytical models for processing spatial data. It combines information systems, databases, and visualization maps. Moreover, it is characterized by its high efficiency in geostatistical analysis and the production of (two- and threedimensional) maps, through the management of spatial data and representation of different-layer shapes depending on the nature of the studied parameters in addition to many other features. The layers in the geographic information system GIS software plays an important role in urban planning process because it has a high capacity to deal with different types of data to facilitate decision making and help in the completion of projects. Therefore, their use has become an indispensable necessity in facilitating urban land planning and can be used in different fields, such as crime management, crisis and disaster management, urban planning, environmental protection, positioning and others.

\section{ARTIFICIAL NEURAL NETWORKS} (ANN) $[8,9,12,13]$

Artificial neural network (ANN) is one of the techniques of artificial intelligence, which can be defined as a mathematical software attempt used to simulate the biological cells in the human brain. It consists of a related set of processing elements in a form of units or nodes called neurons that are connected to each other by a set of associative weights used to determine the activity of the network as a whole, called links 


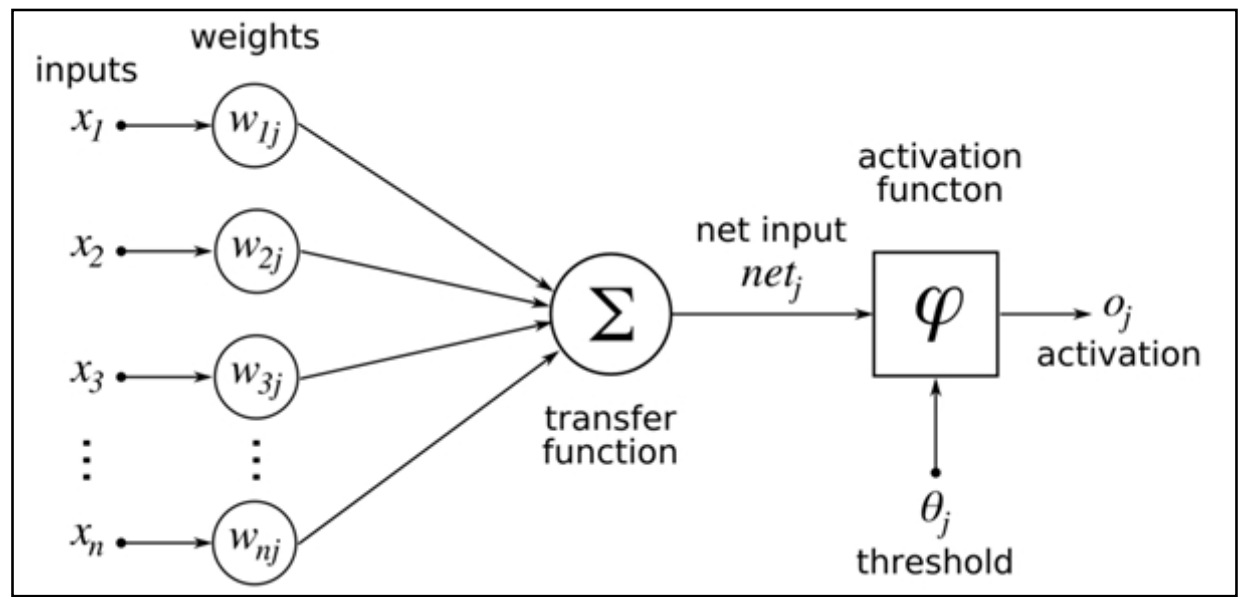

Figure (2): Neural Network Components [12]

each link has its own weight. Every processing element receives the stimulation from the adjacent elements that are connected to it to process data and produces different outputs. Theneurons aredivided, according to the nature of their work, into three types(input neurons receive stimulation from outside the net, output neurons produce outputs, and hidden neurons receive stimulation from the other elements inside the net and stimulate other processing elements).Neural networks derive their power from distributed parallel structures. The nodes connected to each other in parallel way perform several functions at the same time. This is what is called parallel processing. Besides, these nodes have the ability to educate in different ways: supervised, unsupervised, and education through re information. They are also characterized by generalization. The neural networks are divided into different types according to their structure, including the front and back feeding systems. They may be one-layeror multi-layer. They use different types of activation function such as step function and sign function. They have been successfully used in various biologic, medical, economic, environmental and landuse planning applications, etc. Figure (2) illustrates a model artificial neural network.[10,11,14]

\section{APPLICATION MECHANISM}

The work mechanism included three complementary stages applied to the study data, as follows:

\subsection{First Stage: Building a Spatial Information System}

The first stage included several steps that can be clarified as follows:

\subsubsection{Data Collection}

Preliminary data are the basis of the design, analysis and spatial processing processes to obtain more accurate results. They were reflected on both the 2013 Baseline Design map and the Satellite Image of Basrah. The coordinates of school buildings for all stages were recorded. The coordinates of petrol stations and other detailed data were inferred using spatial analysis model applied to the basic design map, which is available in a single layer, which includes all the uses of the urban land in the study area to be divided and to isolate the services from each other and compare what is related to the current study data with obtained preliminary data to examine their correctness.

\subsubsection{Building the Geographic Database}

The Geo-DB is a basic requirement for anyinformation system. Therefore, the data of the present study were organized into different data sets for the implementation of spatial analysis as follows:

A. Data set1: includes four categories of feature classes including school buildings according to educational stages (kindergartens, primary, intermediate, and secondary).

B. Data set2: includes feature classes (main streets, petrol stations, residential quarter's boundaries).

C.Data set3: includes three categories of landmarks (Shatt alArab, channel of Shatt al-Basra, the city limits).

It should be noted that structuring the database in this way helps to facilitate spatial processing and implementation of spatial relations between layers of different landmarks

\subsubsection{Building an Analytical Model [14]}

The GIS environment provides the possibility of working analytical models to simulate the work of tools and to facilitate access to them to save time. There are several advantages for using the constructor of models, such as putting any number of repetitions ina single process, facilitating access to the tools when the outputs of a single process is used as an input to another process, exporting software scripts to other work environments, adding output data as parameters of models on the map. This helps the user to execute the workflow by adding toolbars, input groups and output together in a single graphical environment. That is why the proposed model is designed to conduct a series of processes on the spatial database represented in a schematic diagram to facilitate the execution of processes. Figure (3) illustrates the structure of the model used in the spatial analysis of the current study.

The approved tools for building the model are clarrified below:

1. Make XY Event Tool: This tool provides the possibility to add coordinates data from an external file and assign the values of both latitude and longitude $(\mathrm{X}, \mathrm{Y})$ to the changes $(\mathrm{X}, \mathrm{Y})$ of this tool to projection the coordinates of the school locations on their real places in the study area. 


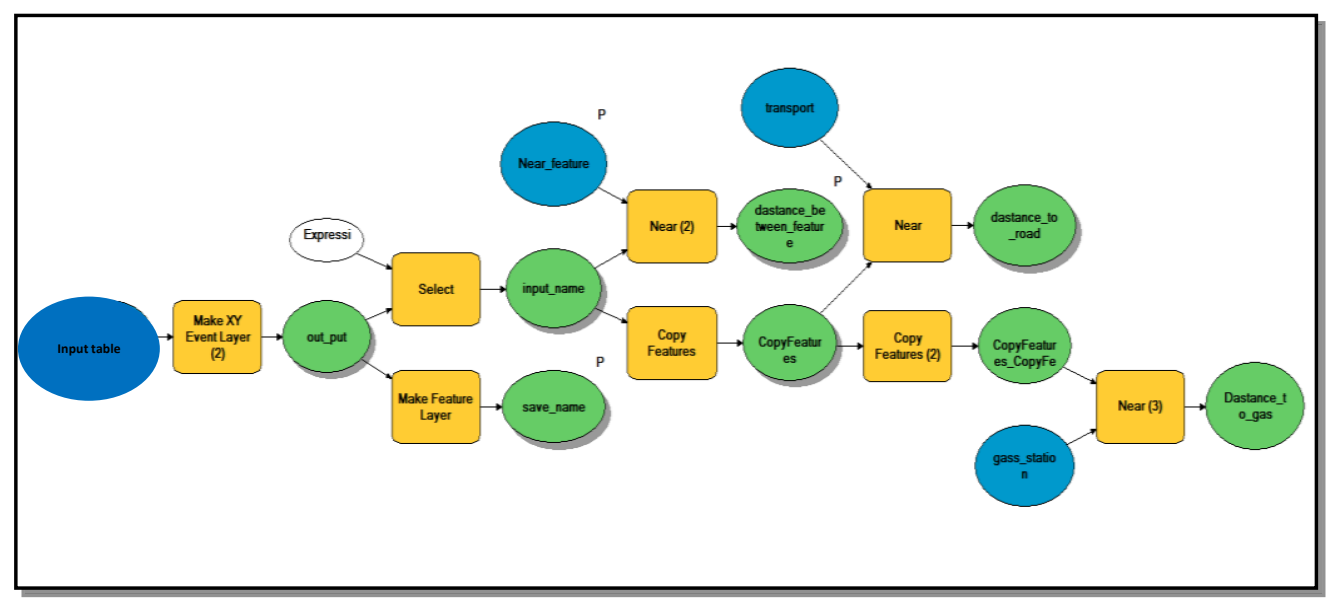

Figure (3): The Proposed Analytical Model in the Spatial Analysis of School Buildings Locations

2. Make Feature Layer Tool: This tool is used to convert the output of the previous tool (building locations) into a separate layer.

3. Copy Feature Tool: This tool is used to copy the required landmarks for analysis and processing.

4. Select Tool: This tool is used to select landmarks according to specific conditions. This is called conditional spatial query.

5. Near tool: - This tool is used to calculate the distance between the studied landmarks to match the results with the specified standards.

\subsection{Second Stage: Design of Artificial Neural Network}

The neural network for evaluating school building locations consists of three layers: the input layer, which consists of four nodes representing the neural network inputs, a hidden layer containing initially 30 nodes and one output layer. The neural network was trained by a training matrix consisting of $[4 *$ $120]$ patterns and an output matrix consisting of [1*120] of patterns. The weights were stabilized after noting that the learning coefficient selection 0.05 and the permissible fault value of 0.005 and the choice of thirty hidden nodes in the medium layer that gives the best results. Figure (4) shows a simplified model of the neural network structure. Figure (5) shows the comparison of the actual output with the desired output of the training data. We observe the relative compatibility of the real output of the network with the desired outpu where we can see the relative conformity of the two outputs. The neural network was then tested by output data of school buildings to evaluate them.

\subsection{Third Stage: Classification [4]}

The classification is one of the most important and most common spatial analyses. It provides a clear explanation of the nature of the studied landmarks and their representation in special maps to determine their optimal uses. Geographic information systems (GIS) provide different classification methods that depend on two factors (number of layers and type of classification required). Natural Breaks represent a standard classification method, providing data types according to the concept of clustering and gaps in it. This is based on natural herarical data setsand in our present study it representsthe neural network ratings which determined conformity to the approved planning criteria.One of the advantage of this method is that any update of the data does not affect its performance, as well as the possibility of control on (number of classes, the exclusion of some spatial features in the layers, change of color totals, rearrangement layers and others).

\section{DISCUSSION OF RESULTS}

The results of the integration of GIS outputs with the neural network of the current study data showed a set of results presented for discussion as follows:

\subsection{Kindergarten Stage}

It was found that (2) of the school buildings were evaluated $(0.23884)$ of the total (30) buildings or $(6.66 \%)$ and 16 school buildings obtained an evaluation of (0.50421) which represents $(53.33 \%)$, while 10 buildings were evaluated $(0.7398)$ which means that they represent $(33.33 \%)$ of the total buildings, and only two buildings were evaluated (0.965) or $(6.66 \%)$. This means that only two buildings have met the criteria which are( Themar Al-Qulub in Shu'la and Ahbab Rahman in Al-Hussein Qurter) and 10 of the buildings have met three planning standards and 16 of the buildings have met two of the standards but the remaining buildings, which are (2), met only one stand as shown in Table (2).

\subsection{Primary School Stage}

It was noticed that one building out of (173) buildings obtained the evaluation (0.02565) by $(0.57 \%)$ and(98) buildings obtained $(0.2388)$, which is $(56.64 \%)$, while 62 school buildings obtained (0.493429), which represents $(35.83 \%)$ of the total buildings, and (10) of the buildings obtained $(0.7398)$, i.e. $(5.78 \%)$ of the total buildings, and only two buildings obtained (0.96517) which represents (1.1 $\%$ ) of the school buildings, indicating that one building did not meet any approved planning standards and that 98 of the buildings had met one planning standard and that (62) of the school buildings had met two planning standardand (10) of them had met three planning standards and only (2) have got perfect matching which are (Al-Nashi'a School in Abellah and Al-Sahabi in Al-Ma'qal) as shown in Table (2). 


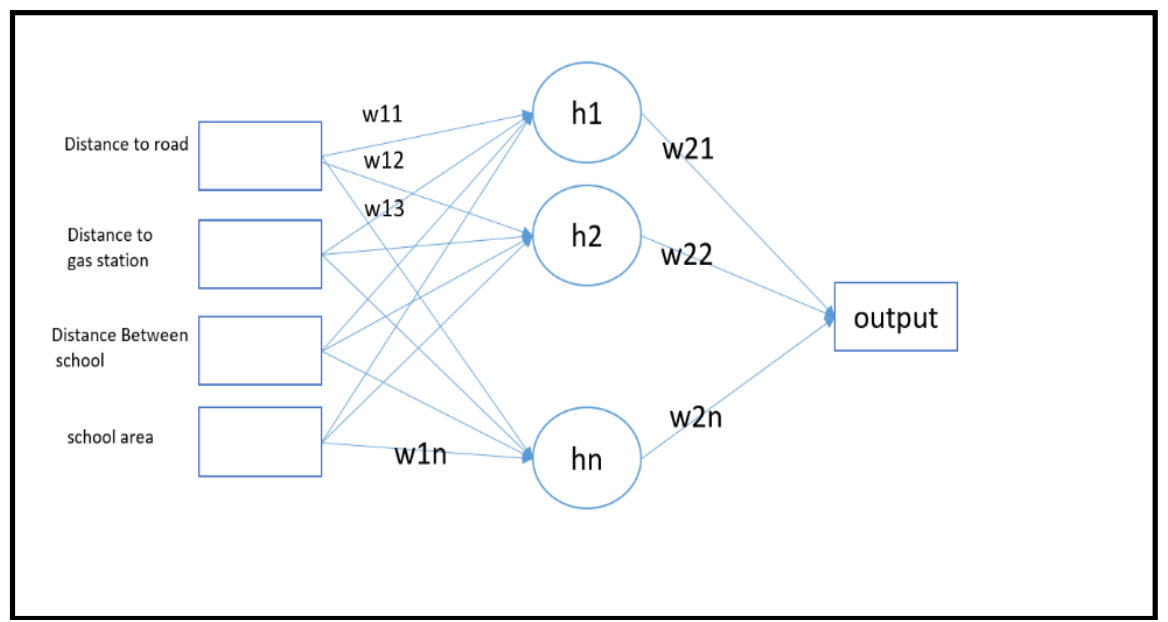

Figure (4): Architectural Structure of the Proposed Neural Network

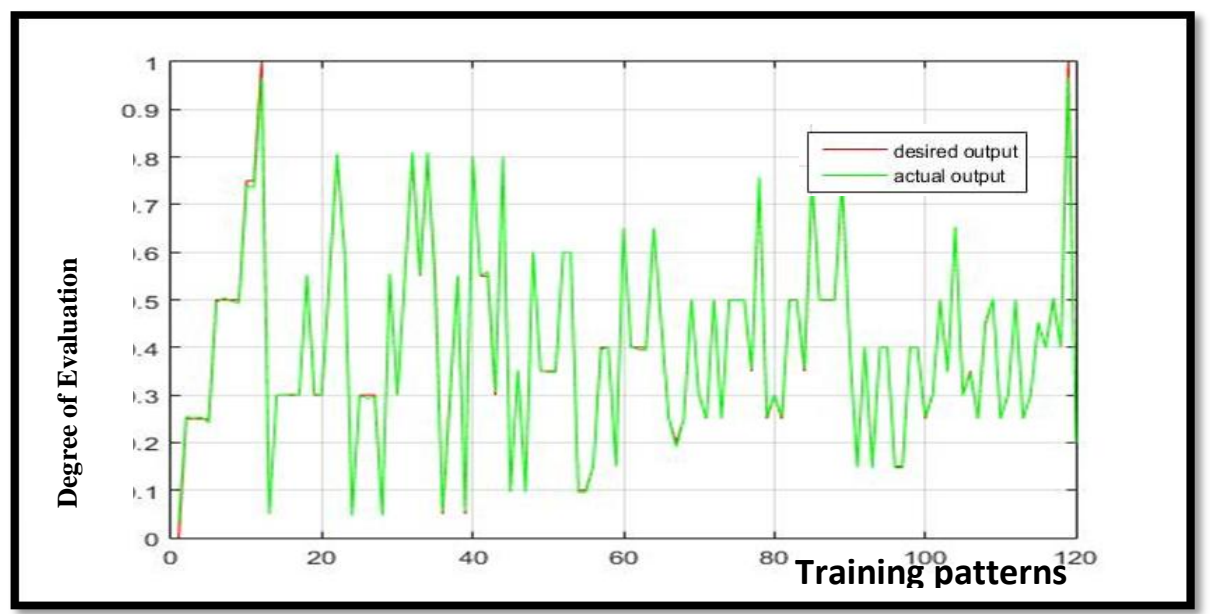

Figure (5): Comparison of the Actual Output with the Desire

\subsection{Intermediate School Stage}

It was found that only one building obtained the evaluation (0.0256) and $(2.4 \%)$ of the total number of school buildings which is (41) and(21) buildings obtained (0.2388) or (51.2\%), while we can see that (14) buildings were evaluated (0.4667), which represents $(34.1 \%)$ of the total buildings, and (4) of them obtained the evaluation $(0.7398)$ or $(9.7 \%)$. Only one building has obtained $(0.96517)$ which represents $(2.4 \%)$. This indicates that one building did not meet any planning standard while (21) met one planning standard, (14)met twoplanning standards , (4)met three standards, and only one building had a perfect match which is Al-Jawaheri School in Al-Methaq Quarter as shown in Table (2).

\subsection{High School Stage}

It was found that (28) out of (42) buildings were evaluated by $(0.23884)$ and $(66.66 \%)$, and (12) buildings were evaluated $(0.50421)$, or $(28.57 \%)$ while only two buildings obtained The $(0.7398)$ by $(4.7 \%)$. As can be noticed in Table (2), (28) of the buildings have met one planning standard and (12) of them have met two standards and only (2) have met three standard. Figure (6) outlines the results of the neural network evaluation of all stages

\subsection{Classification}

After noting the variation in the degree of conformity, the school buildings were classified into multiple categories. Table (3) shows the difference in the number of classes from one stage to another. We find them in kindergarten (4 classes) while (5 classes) in primary and intermediate but (only 3 classes) in high school. This was due to the difference in the degrees of confirmity between the results of the neural network and the approved planning standards. Based on this, school buildings of all stages can be classified in terms of conformity into five classes: ( no conformity(rejected), conform to one standard(unsuitable), conform to two standards( acceptable), conform to three standards(suitable), perfect conformity(good)). Tabe (4) and Figure (7) show the number of school buildings and their perecntages where (rejected) class got $(0.699 \%)$, unsuitable got $(52.097 \%)$, acceptable got $(36.36 \%)$, suitable got $(9.090 \%)$ while (good) class got (1.748\%). Appendix (1) / Figures (8, 9 10, 11) illustrate the classification categories. 
Table 2. Percentage of Neural Network Results by Number of Buildings and Levels of Conformity to the Approved Standards for All Levels

\begin{tabular}{|c|c|c|c|c|c|}
\hline NO & 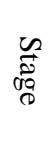 & 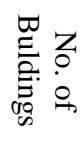 & 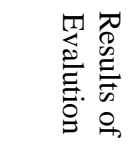 & $\%$ & 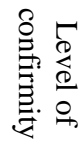 \\
\hline \multirow{4}{*}{1} & \multirow{4}{*}{ 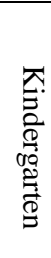 } & 2 & 0.23884 & 6.67 & 1 \\
\hline & & 16 & 0.50421 & 53.33 & 2 \\
\hline & & 10 & 0.7398 & 33.33 & 3 \\
\hline & & 2 & 0.965 & 6.67 & 4 \\
\hline \multirow{5}{*}{2} & \multirow{5}{*}{ 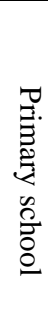 } & 1 & 0.02565 & 0.58 & 0 \\
\hline & & 98 & 0.2388 & 56.65 & 1 \\
\hline & & 62 & 0.49343 & 35.84 & 2 \\
\hline & & 10 & 0.7398 & 5.78 & 3 \\
\hline & & 2 & 0.96517 & 1.16 & 4 \\
\hline \multirow{5}{*}{3} & \multirow{5}{*}{ 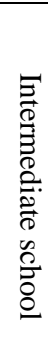 } & 1 & 0.02565 & 2.43 & 0 \\
\hline & & 21 & 0.2388 & 51.21 & 1 \\
\hline & & 14 & 0.4667 & 34.14 & 2 \\
\hline & & 4 & 0.7398 & 9.75 & 3 \\
\hline & & 1 & 0.96517 & 2.43 & 4 \\
\hline \multirow{3}{*}{4} & \multirow{3}{*}{ 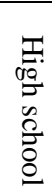 } & 28 & 0.23884 & 66.66 & 1 \\
\hline & & 12 & 0.50421 & 28.57 & 2 \\
\hline & & 2 & 0.7398 & 4.76 & 3 \\
\hline
\end{tabular}

Table 3. Classifications of School Buildings according to Degrees of Conformity for every stage

\begin{tabular}{|c|c|c|c|c|c|}
\hline NO & 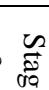 & Class & $\begin{array}{c}\text { No. of } \\
\text { Buildings }\end{array}$ & Value & $\begin{array}{c}\text { Kind of } \\
\text { class }\end{array}$ \\
\hline \multirow{4}{*}{1} & \multirow{4}{*}{ 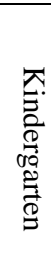 } & First & 2 & 0.23884 & unsuitable \\
\hline & & Second & 16 & 0.50421 & acceptable \\
\hline & & Third & 10 & 0.7398 & Suitable \\
\hline & & Fourth & 2 & 0.965 & good \\
\hline \multirow{5}{*}{2} & \multirow{5}{*}{ 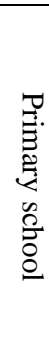 } & First & 1 & 0.02565 & rejected \\
\hline & & Second & 98 & 0.2388 & unsuitable \\
\hline & & Third & 62 & 0.49343 & acceptable \\
\hline & & Fourth & 10 & 0.7398 & Suitable \\
\hline & & Fifth & 2 & 0.96517 & good \\
\hline \multirow{5}{*}{3} & \multirow{5}{*}{ 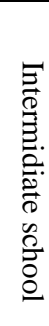 } & First & 1 & 0.02565 & rejected \\
\hline & & Second & 21 & 0.2388 & unsuitable \\
\hline & & Third & 14 & 0.4667 & acceptable \\
\hline & & Fourth & 4 & 0.7398 & Suitable \\
\hline & & Fifth & 1 & 0.96517 & good \\
\hline \multirow{3}{*}{4} & \multirow{3}{*}{ 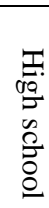 } & First & 28 & 0.23884 & unsuitable \\
\hline & & Second & 12 & 0.50421 & acceptable \\
\hline & & Third & 2 & 0.7398 & Suitable \\
\hline
\end{tabular}




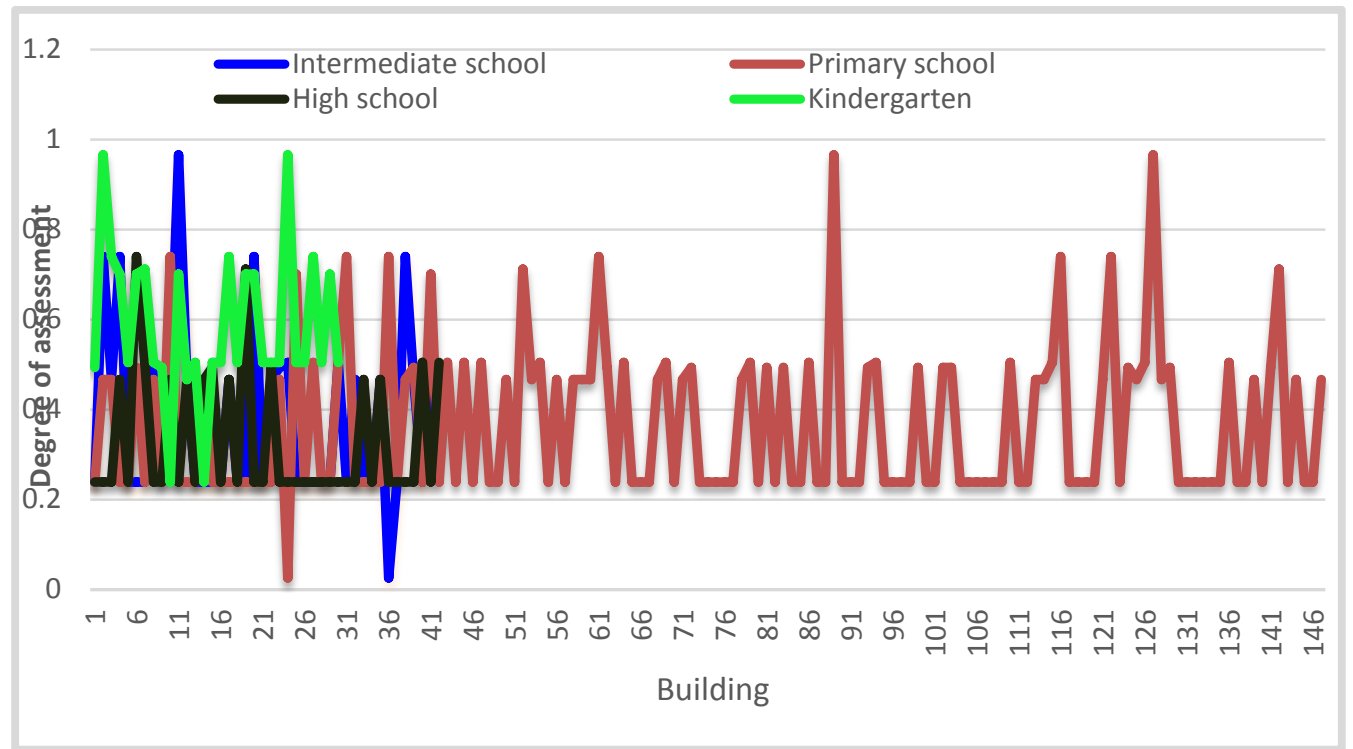

Figure (6): Results of the Neural Network Evaluation for the sites of the Educational Buildings according to Stage

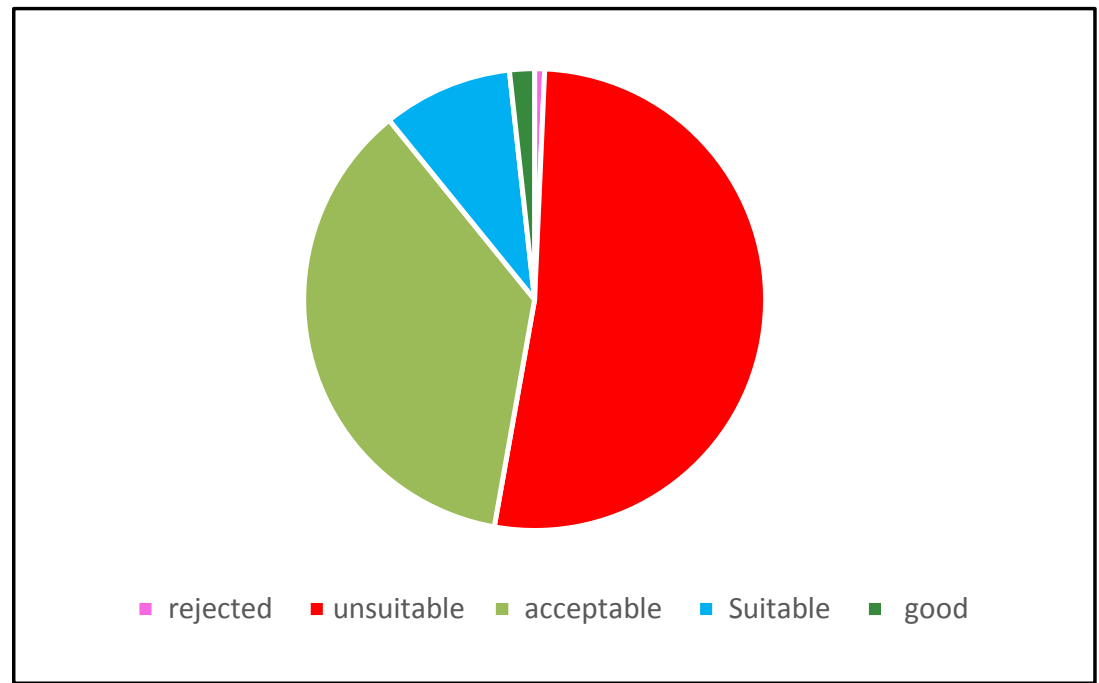

Figure (7): Classification of School Buildings according to to Kind of Approved Conformity of All Stages

\section{CONCLUSION}

Based on the above, it was concluded that:

1. There is a clear variation in the number of categories of classification of school buildings by stages, ranged between (3-5), and this difference is due to the discrepancy in conformity with standards which refers the bad distribution of school buildings and that mostof them aren't found in their correct sites or locations.

2. There is a clear discrepancy among the numbers of school buildings in terms of the kind of conformity of all stages where we can find that the majority of buildings have not obtained perfect conformity (good) and this can be attributed to random planning because there was no prior organisation to the management of educational services projects in the study area.

Therefore, the research recommends the following:
1. The need to adopt the planning standards for the management of educational services projects and commensurate with the rapid population growth and continuous urbanization in the city.

2. The need to carry on studies like the present one to evaluate all community services and city management that takes into consideration the requirements of continous progress.

3. The need to adopt modern techniques in the management of all urban planning projects to assist in the process of supporting decision and the possibility of future prediction of the actual need. Moreover, these techniques can proviode researchers and beneficiaries with detailed spatial databases on urban planning projects that can be updated constantly to find solutions to help solve the problems of failure in all community services and not only education. 
Table 4. Percentages of the Classification of School buildings

\begin{tabular}{|c|c|c|c|c|c|c|}
\hline \multirow[b]{2}{*}{ 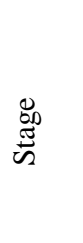 } & \multirow{2}{*}{ 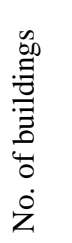 } & \multicolumn{5}{|c|}{ Percentage for kind of classes } \\
\hline & & 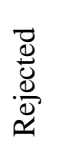 & 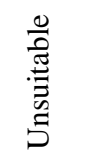 & $\begin{array}{l}\frac{0}{0} \\
\frac{\pi}{0} \\
\stackrel{0}{0} \\
\stackrel{0}{\pi}\end{array}$ & 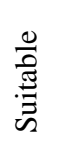 & $\begin{array}{l}\text { ర0 } \\
8 \\
0\end{array}$ \\
\hline 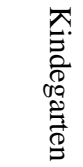 & 30 & - & 2 & 16 & 10 & 2 \\
\hline 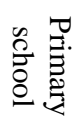 & 173 & 1 & 98 & 62 & 10 & 2 \\
\hline 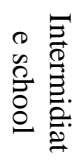 & 41 & 1 & 21 & 14 & 4 & 1 \\
\hline $\begin{array}{l}\frac{T}{0} \\
\stackrel{0}{0} \\
0 \\
0 \\
0 \\
0 \\
0 \\
0\end{array}$ & 42 & - & 28 & 12 & 2 & - \\
\hline$\stackrel{\vec{D}}{\stackrel{D}{D}}$ & 286 & 2 & 149 & 104 & 26 & 5 \\
\hline 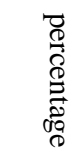 & - & $\begin{array}{c}0.69 \\
9 \%\end{array}$ & $\begin{array}{c}52.097 \\
\%\end{array}$ & $\begin{array}{c}36.363 \\
\%\end{array}$ & $\begin{array}{c}9.090 \\
\%\end{array}$ & $\begin{array}{c}1.74 \\
8\end{array}$ \\
\hline
\end{tabular}

\section{REFERENCES}

[1] Al-Nassir, Khadejah A. Hussein and Ali A. Khedheer. (2016). 'The Theoretical Frameworks and Technical Scientific Methods of Geo-Information Science'. Iraqi Journal of Information Technology, Vol. 7, No. 2.

[2] Jabir, Zeenah Ayad and Ali H. Saad. 'Spatial Analysis of the Sites of Government Schools in the City of Najaf
Using Geographic Information Systems'.Available at: www.uokufa.edu.iq/journals/index.php./kufa arts/article/view/348. Accessed 22 September, 2017.

[3] Al-Kahby, Murtada Mudafer. (2017). 'Spatial Analysis of the Change in Residential Land Use in Basrah City by Using Remote Sensing and Graphic Information Systems, Part1'. PhD. Thesis. University of Basrah

[4] Al-Zuhairi, Ammar A. Dayish. (2016). 'Reality of Enteretainment Services in Basrah City and Methods of Developing Them: A Study in Urban Geography'. Masters Thesis. University of Basrah.

[5] Abood, Salman Maghamis. (2012). 'Educational Land Uses and Real Disparity in Basrah City (1977-2007)'. PhD Thesis. University of Basrh.

[6] Jabir, Zeenah Ayad and Ali H. Saad. 'Spatial Analysis of the Sites of Government Schools in the City of Najaf Using Geographic Information Systems'. Available at: www. uokufa.edu.iq/journals/index.php./kufa arts/article/view/348. Accessed 22 September, 2017.

[7] Nooshi ,Wasan.(2009). spacial suitabilty of urban planning Efficiency and its impact on people of basrah city. Master thesis. University of Basra

[8] Basheer, I. A., \& Hajmeer, M. (2000). 'Artificial neural networks: fundamentals, computing, design, and application. Journal of microbiological methods', 43(1), 3-31.

[9] da Cruz Albuquerque ‘H. C. 'Cardoso Pedrosa Martins ، F. M. ‘\& Tomás Galiza Cardoso ‘L. M. (2014). Geographical information systems 'tourism (pp. 1-3). Springer International Publishing.

[10] Sharma ‘H. S. ‘Prasad ‘R. ‘\& Binda ‘P. R. (2006). Mathematical Modeling In GeographicalInformation System (GIS) \& GPS An Overview. Concept Publishing Company.

[11] Wadah Razoqi . (2010) agricultural lands classification on GIS Using Neural Network.Master thesis, University of Babylon

[12] Araghinejad, S. (2014). 'Artificial neural networks'. In Data-Driven Modeling: Using MATLAB ${ }^{\circledR}$ in Water Resources and Environmental Engineering (pp. 139194). Springer:Netherlands.

[13] Kubat, M. (2017). Artificial neural networks. In An Introduction to Machine Learning (pp. 91-111).Springer.

[14] Lowe, M. (2014). Night lights and ArcGis: A brief guide. Avaliable online: http://economics. mit. edu/files/8945 (accessed on 22 August 2014). 


\section{APPENDIX}

\section{Appendix (1)}

Classification of school Buildings of all study stages

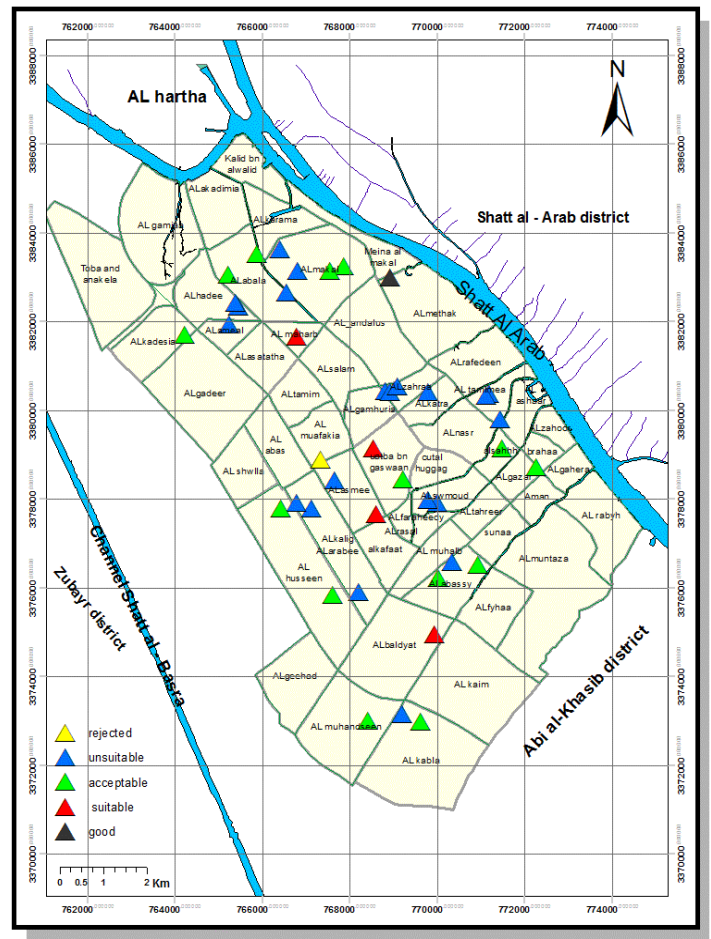

Figure (8): Classification of kindergartens building

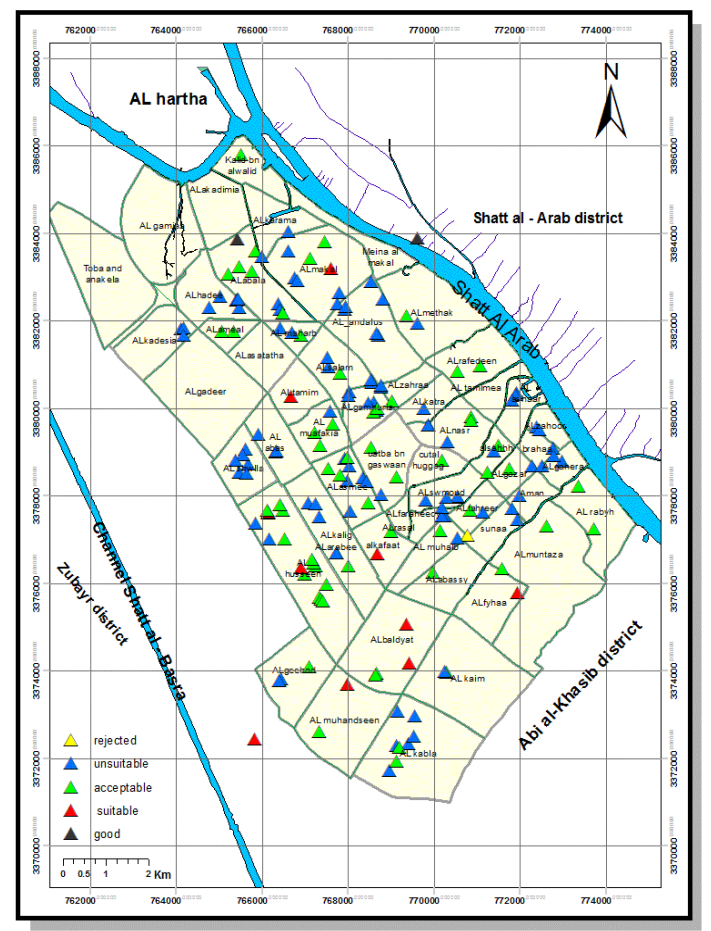

Figure (9) : Classification of primary school buildings

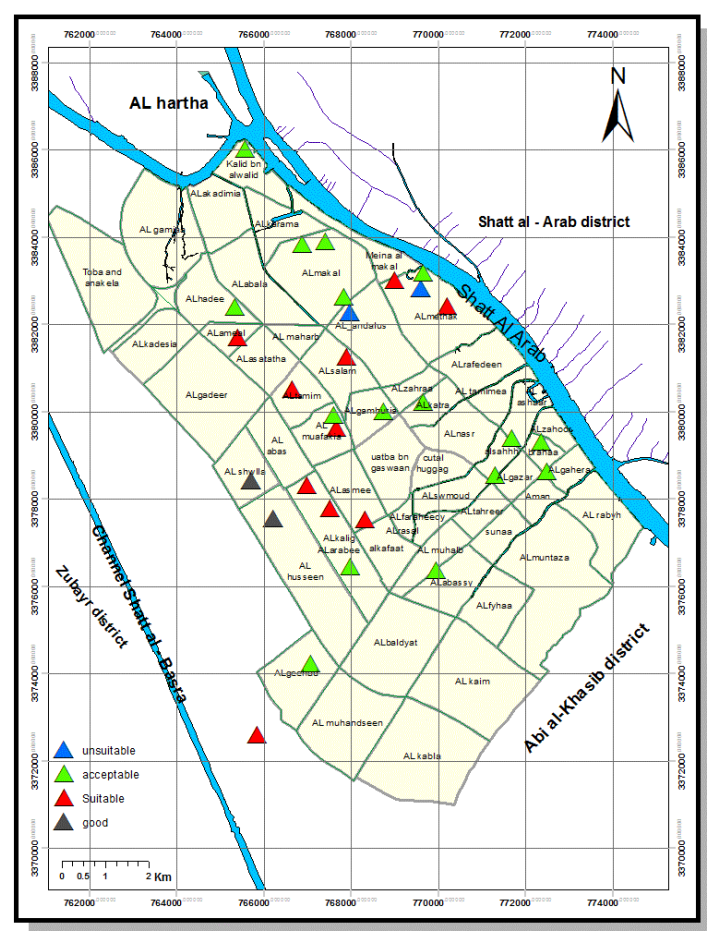

Figure (10) : Classification of Intermediate school buildings

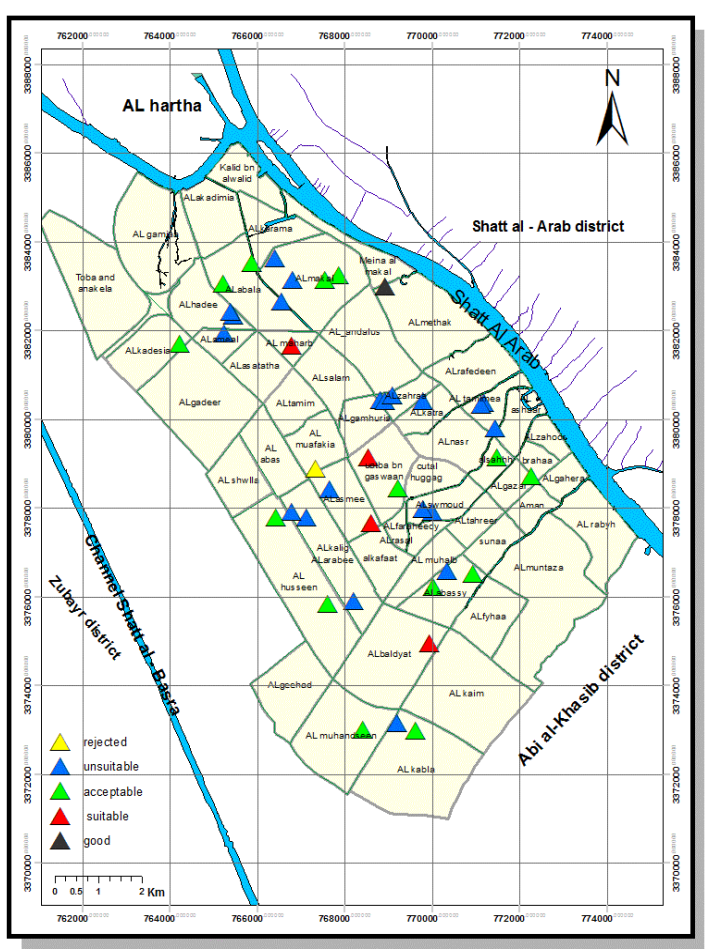

Figure (11) : Classification of High school buildings 
Appendix (2) Results of Spatial Analysis and Nueral Network of all stages

Table 1 . Kindergarten stage

\begin{tabular}{|c|c|c|c|c|c|c|c|}
\hline code & $\begin{array}{l}\text { Longtitude } \\
\text { (x) }\end{array}$ & Latitude(y) & $\begin{array}{c}\text { Distance to } \\
\text { petrol } \\
\text { station }\end{array}$ & $\begin{array}{l}\text { Distance } \\
\text { between } \\
\text { schools }\end{array}$ & $\begin{array}{l}\text { Distance to } \\
\text { main street }\end{array}$ & $\begin{array}{c}\text { Area of } \\
\text { school }\end{array}$ & $\begin{array}{c}\text { Result of } \\
\text { evaluation }\end{array}$ \\
\hline 1 & 767829.7 & 3382635 & 124.2524 & 380.6889 & 117.3731 & 4200 & 0.493429 \\
\hline 2 & 765701.7 & 3378422 & 705.8539 & 998.9479 & 187.2743 & 4200 & 0.965179 \\
\hline 3 & 768984.7 & 3383028 & 1025.311 & 645.5042 & 198.355 & 1300 & 0.739891 \\
\hline 4 & 768307.9 & 3377535 & 1059.718 & 838.2013 & 119.3396 & 3000 & 0.700573 \\
\hline 5 & 766872.7 & 3383852 & 1433.592 & 534.1011 & 23.97202 & 2000 & 0.504218 \\
\hline 6 & 766637 & 3380516 & 1671.861 & 1113.77 & 22.84219 & 3600 & 0.700573 \\
\hline 7 & 767641.7 & 3379632 & 534.8029 & 308.2473 & 242.7132 & 3600 & 0.712045 \\
\hline 8 & 767402.6 & 3383919 & 1378.605 & 534.1011 & 104.4668 & 2000 & 0.504218 \\
\hline 9 & 767587.8 & 3379936 & 785.2598 & 308.2473 & 80.71709 & 3600 & 0.493429 \\
\hline 10 & 769598.9 & 3382829 & 1587.15 & 372.43 & 100.9536 & 1500 & 0.23885 \\
\hline 11 & 765379.1 & 3381715 & 675.2793 & 689.7285 & 10.82347 & 3600 & 0.700573 \\
\hline 12 & 769646.3 & 3383198 & 1707.032 & 372.43 & 200.9985 & 2700 & 0.466781 \\
\hline 13 & 765560.3 & 3386019 & 3653.833 & 2533.219 & 76.99697 & 600 & 0.504218 \\
\hline 14 & 767979.5 & 3382285 & 362.2903 & 380.6889 & 29.86988 & 2400 & 0.23885 \\
\hline 15 & 768724.6 & 3380011 & 945.9922 & 939.3119 & 15.76548 & 1600 & 0.504218 \\
\hline 16 & 772479.3 & 3378628 & 1559.908 & 697.6861 & 30.04402 & 400 & 0.504218 \\
\hline 17 & 765838.6 & 3372598 & 793.2811 & 2032.339 & 692.4693 & 200 & 0.739891 \\
\hline 18 & 771282.5 & 3378553 & 409.8882 & 934.8341 & 11.46491 & 800 & 0.504218 \\
\hline 19 & 770180.9 & 3382427 & 1351.271 & 707.393 & 84.35599 & 3000 & 0.700573 \\
\hline 20 & 767506.9 & 3377782 & 1091.798 & 767.1433 & 127.2008 & 5400 & 0.700573 \\
\hline 21 & 769638.1 & 3380230 & 913.8846 & 939.3119 & 73.58733 & 2400 & 0.504218 \\
\hline 22 & 769935.4 & 3376382 & 809.921 & 1964.692 & 0.62576 & 1200 & 0.504218 \\
\hline 23 & 765332.7 & 3382403 & 233.5979 & 689.7285 & 31.75814 & 2400 & 0.504218 \\
\hline 24 & 766202.3 & 3377558 & 875.7714 & 998.9479 & 264.0967 & 3600 & 0.965179 \\
\hline 25 & 771665.2 & 3379405 & 987.9165 & 689.268 & 19.43828 & 1125 & 0.504218 \\
\hline 26 & 767050.6 & 3374230 & 733.5689 & 2032.339 & 83.76482 & 900 & 0.504218 \\
\hline 27 & 766969.9 & 3378329 & 585.9335 & 767.1433 & 153.4136 & 2500 & 0.739891 \\
\hline 28 & 767972.1 & 3376457 & 863.4426 & 1128.756 & 92.41888 & 2068 & 0.504218 \\
\hline 29 & 767875.1 & 3381253 & 1020.005 & 1037.777 & 16.97863 & 4200 & 0.700573 \\
\hline 30 & 772348.2 & 3379313 & 1530.341 & 689.268 & 4.920259 & 500 & 0.504218 \\
\hline
\end{tabular}


Table 2. Primary Stage

\begin{tabular}{|c|c|c|c|c|c|c|c|}
\hline code & Longtitude(x) & Latitude(y) & $\begin{array}{c}\text { Distance to } \\
\text { petrol station }\end{array}$ & $\begin{array}{c}\text { Distance } \\
\text { between } \\
\text { schools }\end{array}$ & $\begin{array}{l}\text { Distance to } \\
\text { main street }\end{array}$ & $\begin{array}{l}\text { Area of } \\
\text { school }\end{array}$ & $\begin{array}{c}\text { Result of } \\
\text { evaluation }\end{array}$ \\
\hline 1 & 772987.1 & 3378783 & 2062.95998 & 234.317 & 125.3557 & 2136 & 0.23885 \\
\hline 2 & 771496 & 3379145 & 693.667628 & 170.2393 & 185.8766 & 3000 & 0.466781 \\
\hline 3 & 766490.4 & 3377667 & 1136.82224 & 148.9231 & 230.4201 & 4900 & 0.466781 \\
\hline 4 & 769405.8 & 3372332 & 366.084083 & 209.1813 & 43.95898 & 2500 & 0.23885 \\
\hline 5 & 767336.4 & 3377506 & 1339.62038 & 313.8418 & 98.00953 & 4000 & 0.23885 \\
\hline 6 & 765339 & 3381744 & 660.275007 & 271.2918 & 15.3567 & 6720 & 0.493429 \\
\hline 7 & 769873.7 & 3379601 & 781.8398 & 0 & 51.57347 & 3600 & 0.23885 \\
\hline 8 & 768663.1 & 3373947 & 909.149867 & 57.47391 & 293.8064 & 2800 & 0.466781 \\
\hline 9 & 769164.6 & 3373079 & 966.474405 & 407.6648 & 94.88119 & 4500 & 0.23885 \\
\hline 10 & 765823 & 3372432 & 723.111618 & 1453.547 & 682.3139 & 2400 & 0.739891 \\
\hline 11 & 770556.5 & 3377967 & 867.131253 & 6.165874 & 128.9978 & 4350 & 0.23885 \\
\hline 12 & 769552.9 & 3372955 & 665.045161 & 407.6648 & 140.2767 & 3600 & 0.23885 \\
\hline 13 & 771150.3 & 3377625 & 668.435385 & 310.9575 & 11.07522 & 2000 & 0.23885 \\
\hline 14 & 767342 & 3375683 & 688.57535 & 62.74691 & 266.4335 & 2400 & 0.466781 \\
\hline 15 & 769812.7 & 3377896 & 1041.41125 & 409.3725 & 111.9011 & 4589 & 0.23885 \\
\hline 16 & 767992.5 & 3378350 & 889.834105 & 221.2034 & 55.77643 & 3500 & 0.23885 \\
\hline 17 & 768606.6 & 3380133 & 968.99313 & 131.172 & 35.76537 & 2500 & 0.23885 \\
\hline 18 & 767797.2 & 3382644 & 156.195097 & 271.7926 & 147.6499 & 2200 & 0.23885 \\
\hline 19 & 767739.3 & 3376691 & 1132.4566 & 8.02602 & 103.6925 & 3500 & 0.23885 \\
\hline 20 & 766612.1 & 3383595 & 1216.90933 & 430.1058 & 12.39684 & 3600 & 0.23885 \\
\hline 21 & 766446.9 & 3373812 & 1330.85281 & 64.69482 & 18.38737 & 4000 & 0.23885 \\
\hline 22 & 772389 & 3379560 & 1673.0044 & 86.24537 & 70.8328 & 1800 & 0.23885 \\
\hline 23 & 769370.9 & 3382111 & 1136.2014 & 310.3619 & 210.8663 & 4200 & 0.466781 \\
\hline 24 & 770788 & 3377082 & 44.6938173 & 249.4324 & 0 & 3000 & 0.025651 \\
\hline 25 & 771943.9 & 3375775 & 1782.32014 & 654.7437 & 107.2168 & 6904 & 0.700573 \\
\hline 26 & 765684.2 & 3378724 & 975.073005 & 226.3775 & 20.11565 & 2400 & 0.23885 \\
\hline 27 & 769981.7 & 3376255 & 694.723968 & 953.5777 & 102.453 & 2500 & 0.504218 \\
\hline 28 & 768535.5 & 3382901 & 560.551892 & 495.1563 & 87.39162 & 3360 & 0.23885 \\
\hline 29 & 770253 & 3377534 & 659.715647 & 57.02731 & 0 & 2700 & 0.23885 \\
\hline 30 & 773721.6 & 3377236 & 2980.19632 & 1045.113 & 105.1971 & 3600 & 0.504218 \\
\hline 31 & 769358.6 & 3375063 & 687.277771 & 897.3423 & 300.3407 & 2500 & 0.739891 \\
\hline 32 & 768823.9 & 3382499 & 826.949232 & 495.1563 & 23.78438 & 3000 & 0.23885 \\
\hline 33 & 772453.8 & 3379504 & 1704.19941 & 86.24537 & 74.30337 & 1750 & 0.23885 \\
\hline 34 & 771920.7 & 3380345 & 1879.40583 & 40.57475 & 58.82031 & 4600 & 0.23885 \\
\hline 35 & 771999.6 & 3378011 & 1305.98463 & 359.9565 & 16.12231 & 2827 & 0.23885 \\
\hline 36 & 769425 & 3374168 & 1464.91133 & 793.466 & 216.6286 & 2500 & 0.739891 \\
\hline 37 & 768672.2 & 3379953 & 867.587988 & 42.87929 & 17.53631 & 3000 & 0.23885 \\
\hline 38 & 766993.9 & 3376212 & 693.13896 & 156.6448 & 214.068 & 2500 & 0.466781 \\
\hline
\end{tabular}




\begin{tabular}{|c|c|c|c|c|c|c|c|}
\hline 39 & 768013.5 & 3376395 & 799.815889 & 399.443 & 17.88249 & 10000 & 0.493429 \\
\hline 40 & 768956.3 & 3371714 & 1020.60939 & 281.8938 & 7.713769 & 3600 & 0.23885 \\
\hline 41 & 766683.8 & 3380269 & 1534.84807 & 963.5169 & 45.09262 & 6000 & 0.700573 \\
\hline 42 & 765423.2 & 3382498 & 192.7027 & 23.03929 & 29.22564 & 2603 & 0.23885 \\
\hline 43 & 771082.3 & 3380974 & 1189.48041 & 553.584 & 0 & 3304 & 0.504218 \\
\hline 44 & 772778.7 & 3379079 & 1882.93113 & 172.2396 & 63.83399 & 1250 & 0.23885 \\
\hline 45 & 769128.7 & 3378426 & 610.459454 & 533.1421 & 28.19825 & 3000 & 0.504218 \\
\hline 46 & 766401.9 & 3373765 & 1383.60534 & 64.69482 & 11.98279 & 2400 & 0.23885 \\
\hline 47 & 771758.4 & 3378625 & 843.538127 & 508.4629 & 7.423575 & 2000 & 0.504218 \\
\hline 48 & 770552.7 & 3377971 & 864.386331 & 6.165874 & 135.149 & 4550 & 0.23885 \\
\hline 49 & 765411.8 & 3382473 & 185.661768 & 27.42611 & 38.71558 & 2400 & 0.23885 \\
\hline 50 & 768476.7 & 3377833 & 1109.02391 & 356.7892 & 176.8562 & 3000 & 0.466781 \\
\hline 51 & 765475.2 & 3382296 & 111.998531 & 187.8857 & 30.78799 & 4200 & 0.23885 \\
\hline 52 & 766919.2 & 3376350 & 627.821448 & 156.6448 & 249.3254 & 6724 & 0.712045 \\
\hline 53 & 765862.1 & 3383599 & 1269.35485 & 193.405 & 203.9459 & 3600 & 0.466781 \\
\hline 54 & 765514.6 & 3385795 & 3430.25559 & 1934.584 & 29.25522 & 3600 & 0.504218 \\
\hline 55 & 768354 & 3378400 & 962.010628 & 116.9509 & 26.05565 & 2400 & 0.23885 \\
\hline 56 & 767827.9 & 3380798 & 1389.783 & 314.0585 & 217.2344 & 3600 & 0.466781 \\
\hline 57 & 768778.5 & 3380488 & 1280.37073 & 30.65431 & 28.2679 & 4200 & 0.23885 \\
\hline 58 & 767250.6 & 3376403 & 963.398749 & 62.7395 & 242.3168 & 2500 & 0.466781 \\
\hline 59 & 767647.6 & 3379625 & 525.997526 & 316.1989 & 237.9484 & 2400 & 0.466781 \\
\hline 60 & 766910.7 & 3381660 & 536.498416 & 216.543 & 179.8538 & 3600 & 0.466781 \\
\hline 61 & 767991.1 & 3373681 & 425.495737 & 680.1873 & 195.8309 & 4200 & 0.739891 \\
\hline 62 & 769127.1 & 3371938 & 753.181372 & 281.8938 & 21.72046 & 9600 & 0.493429 \\
\hline 63 & 767931.8 & 3378849 & 494.200968 & 62.34108 & 16.89003 & 3600 & 0.23885 \\
\hline 64 & 767093.3 & 3374088 & 667.045465 & 702.842 & 25.65039 & 3500 & 0.504218 \\
\hline 65 & 766425.8 & 3381824 & 778.199592 & 295.4947 & 100.5706 & 2500 & 0.23885 \\
\hline 66 & 765462 & 3378529 & 732.452324 & 187.3155 & 9.504369 & 4200 & 0.23885 \\
\hline 67 & 768570.7 & 3380586 & 1357.10128 & 72.91899 & 25.45275 & 3000 & 0.23885 \\
\hline 68 & 766157.4 & 3377611 & 818.591123 & 2.552665 & 253.3066 & 4800 & 0.466781 \\
\hline 69 & 767343.8 & 3372601 & 819.448934 & 1258.985 & 19.80384 & 4200 & 0.504218 \\
\hline 70 & 771816.9 & 3377701 & 1231.91552 & 268.0621 & 25.61516 & 2400 & 0.23885 \\
\hline 71 & 767363.3 & 3379155 & 331.013995 & 315.803 & 249.7128 & 2000 & 0.466781 \\
\hline 72 & 769035.3 & 3380153 & 1268.98058 & 387.5466 & 38.3308 & 7315 & 0.493429 \\
\hline 73 & 768532.5 & 3380648 & 1402.24436 & 72.91899 & 36.11142 & 2400 & 0.23885 \\
\hline 74 & 769125.5 & 3372277 & 648.22839 & 73.13358 & 86.53851 & 3600 & 0.23885 \\
\hline 75 & 769759 & 3379982 & 1090.34273 & 397.8572 & 74.74253 & 2849 & 0.23885 \\
\hline 76 & 768765.4 & 3380515 & 1278.87708 & 30.65431 & 32.53961 & 3000 & 0.23885 \\
\hline 77 & 766316.7 & 3378990 & 946.486583 & 35.74897 & 145.8928 & 2600 & 0.23885 \\
\hline 78 & 767230.8 & 3379441 & 598.63459 & 315.803 & 430.3445 & 3600 & 0.466781 \\
\hline 79 & 767126.9 & 3383431 & 1031.53717 & 502.0947 & 32.33969 & 3000 & 0.504218 \\
\hline
\end{tabular}




\begin{tabular}{|c|c|c|c|c|c|c|c|}
\hline 80 & 766702.9 & 3381721 & 656.268848 & 216.543 & 54.12208 & 4900 & 0.23885 \\
\hline 81 & 768612.5 & 3379911 & 796.345701 & 72.88706 & 19.08598 & 5000 & 0.493429 \\
\hline 82 & 766344.9 & 3379012 & 922.4454 & 35.74897 & 117.87 & 1800 & 0.23885 \\
\hline 83 & 770296.8 & 3373964 & 1689.2937 & 41.94688 & 71.72439 & 6860 & 0.493429 \\
\hline 84 & 765647.1 & 3378500 & 753.070359 & 187.3155 & 92.10057 & 3750 & 0.23885 \\
\hline 85 & 769630.1 & 3381940 & 877.254992 & 310.3619 & 114.4189 & 3600 & 0.23885 \\
\hline 86 & 770547.3 & 3380832 & 702.630252 & 553.584 & 25.40488 & 2560 & 0.504218 \\
\hline 87 & 766381.6 & 3382383 & 546.315744 & 131.4559 & 8.181784 & 4200 & 0.23885 \\
\hline 88 & 767587.8 & 3379936 & 785.259805 & 316.1989 & 80.71709 & 2400 & 0.23885 \\
\hline 89 & 769630.1 & 3383887 & 2010.49926 & 1472.966 & 473.843 & 10000 & 0.965179 \\
\hline 90 & 768778.3 & 3378024 & 1097.85253 & 356.7892 & 72.80429 & 3000 & 0.23885 \\
\hline 91 & 765612.5 & 3379062 & 1282.9508 & 141.7693 & 26.08865 & 4400 & 0.23885 \\
\hline 92 & 771941.1 & 3377463 & 1251.9374 & 268.0621 & 91.25371 & 1600 & 0.23885 \\
\hline 93 & 767542.5 & 3378620 & 366.646149 & 304.2848 & 4.436603 & 6300 & 0.493429 \\
\hline 94 & 773372.3 & 3378221 & 2504.80255 & 681.3752 & 44.89538 & 3600 & 0.504218 \\
\hline 95 & 767752.7 & 3382376 & 337.112975 & 199.6513 & 7.192038 & 2400 & 0.23885 \\
\hline 96 & 769873.7 & 3379601 & 781.8398 & 0 & 51.57347 & 2500 & 0.23885 \\
\hline 97 & 768022.6 & 3380366 & 1045.72567 & 72.46184 & 33.77739 & 3600 & 0.23885 \\
\hline 98 & 772788 & 3378907 & 1870.03678 & 172.2396 & 25.11763 & 2000 & 0.23885 \\
\hline 99 & 765758.2 & 3383126 & 785.317654 & 307.8296 & 20.17503 & 5880 & 0.493429 \\
\hline 100 & 768035.7 & 3378677 & 645.71342 & 198.7209 & 68.84618 & 4500 & 0.23885 \\
\hline 101 & 770196 & 3377536 & 704.940872 & 57.02731 & 10.00025 & 1200 & 0.23885 \\
\hline 102 & 767810.8 & 3378476 & 668.687308 & 221.2034 & 83.17502 & 5400 & 0.493429 \\
\hline 103 & 770148.6 & 3377196 & 604.876015 & 343.7677 & 99.45085 & 5000 & 0.493429 \\
\hline 104 & 768057.1 & 3377652 & 1335.969 & 457.314 & 140.2018 & 4000 & 0.23885 \\
\hline 105 & 766424.7 & 3382259 & 527.153394 & 111.1262 & 37.26622 & 2500 & 0.23885 \\
\hline 106 & 768703.3 & 3381672 & 1222.74324 & 41.8 & 33.42368 & 3600 & 0.23885 \\
\hline 107 & 772297.5 & 3378681 & 1374.93425 & 225.812 & 20.8697 & 4200 & 0.23885 \\
\hline 108 & 770257.8 & 3373980 & 1663.55888 & 41.94688 & 51.69142 & 4500 & 0.23885 \\
\hline 109 & 767082.6 & 3377827 & 1030.4162 & 166.5128 & 14.42969 & 2500 & 0.23885 \\
\hline 110 & 768550.4 & 3379095 & 524.868617 & 603.4469 & 123.5726 & 2500 & 0.504218 \\
\hline 111 & 771906.4 & 3380308 & 1839.6394 & 40.57475 & 96.94002 & 4200 & 0.23885 \\
\hline 112 & 768477.6 & 3380109 & 883.611296 & 131.172 & 6.431507 & 3627 & 0.23885 \\
\hline 113 & 765067.9 & 3381754 & 786.387104 & 271.2918 & 159.0328 & 3000 & 0.466781 \\
\hline 114 & 766524.5 & 3377013 & 805.308892 & 356.2934 & 260.2486 & 3600 & 0.466781 \\
\hline 115 & 771594.7 & 3376329 & 1143.34344 & 654.7437 & 0 & 4096 & 0.504218 \\
\hline 116 & 767599.8 & 3383193 & 650.572141 & 529.8272 & 229.754 & 3000 & 0.739891 \\
\hline 117 & 764117.3 & 3381822 & 692.950891 & 70.62195 & 20.10049 & 2700 & 0.23885 \\
\hline 118 & 767546 & 3380937 & 1165.70901 & 215.4371 & 98.52701 & 2400 & 0.23885 \\
\hline 119 & 768669.9 & 3381697 & 1183.31286 & 41.8 & 22.48871 & 1690 & 0.23885 \\
\hline 120 & 766764.7 & 3382969 & 573.12389 & 90.64248 & 26.34102 & 3600 & 0.23885 \\
\hline
\end{tabular}




\begin{tabular}{|c|c|c|c|c|c|c|c|}
\hline 121 & 768636.6 & 3373896 & 889.480603 & 57.47391 & 298.7375 & 3600 & 0.466781 \\
\hline 122 & 768683.1 & 3376679 & 655.225992 & 604.9103 & 233.7727 & 2400 & 0.739891 \\
\hline 123 & 770297 & 3377951 & 967.435127 & 256.5095 & 39.78267 & 4256 & 0.23885 \\
\hline 124 & 769190 & 3372243 & 587.903543 & 73.13358 & 65.16451 & 5400 & 0.493429 \\
\hline 125 & 767375.5 & 3375630 & 650.443257 & 59.43741 & 262.0753 & 3600 & 0.466781 \\
\hline 126 & 767455.3 & 3383811 & 1259.00171 & 502.0947 & 1.100972 & 3000 & 0.504218 \\
\hline 127 & 765421.4 & 3383863 & 1504.2618 & 513.6796 & 261.2071 & 8400 & 0.965179 \\
\hline 128 & 766421.4 & 3377799 & 1059.68091 & 148.9231 & 240.5296 & 4200 & 0.466781 \\
\hline 129 & 767990.3 & 3378871 & 459.165481 & 62.34108 & 10.51578 & 7128 & 0.493429 \\
\hline 130 & 765995.8 & 3383459 & 1176.38128 & 193.405 & 83.04806 & 3600 & 0.23885 \\
\hline 131 & 767247.9 & 3377807 & 1035.83006 & 166.5128 & 15.61058 & 4200 & 0.23885 \\
\hline 132 & 764187.7 & 3381826 & 757.89921 & 70.62195 & 0 & 4200 & 0.23885 \\
\hline 133 & 765556.4 & 3378931 & 1144.69153 & 141.7693 & 22.94536 & 2500 & 0.23885 \\
\hline 134 & 770182.4 & 3377720 & 841.61046 & 184.1444 & 129.21 & 1720 & 0.23885 \\
\hline 135 & 765917.9 & 3379398 & 1444.54765 & 454.108 & 128.1655 & 2200 & 0.23885 \\
\hline 136 & 772625.2 & 3377314 & 1893.21404 & 700.1287 & 25.82366 & 4200 & 0.504218 \\
\hline 137 & 765442.9 & 3382486 & 170.258636 & 23.03929 & 24.93581 & 2400 & 0.23885 \\
\hline 138 & 768011.8 & 3380294 & 974.828327 & 72.46184 & 40.81295 & 2400 & 0.23885 \\
\hline 139 & 767210.3 & 3376451 & 933.500254 & 62.7395 & 265.1338 & 3000 & 0.466781 \\
\hline 140 & 772523.3 & 3378678 & 1600.63065 & 225.812 & 23.78344 & 3000 & 0.23885 \\
\hline 141 & 765217.2 & 3383067 & 782.768796 & 306.3903 & 129.3855 & 6000 & 0.493429 \\
\hline 142 & 766155.6 & 3377613 & 816.409922 & 2.552665 & 252.7237 & 5600 & 0.712045 \\
\hline 143 & 768444.1 & 3378326 & 1061.33576 & 116.9509 & 1.703676 & 3200 & 0.23885 \\
\hline 144 & 767508.2 & 3375963 & 634.491139 & 325.8157 & 231.1194 & 3000 & 0.466781 \\
\hline 145 & 764174.6 & 3381666 & 810.511221 & 160.5677 & 21.45622 & 3000 & 0.23885 \\
\hline 146 & 765389.6 & 3378817 & 1013.60734 & 202.4383 & 25.54031 & 4200 & 0.23885 \\
\hline 147 & 767412.8 & 3375584 & 612.247961 & 59.43741 & 203.194 & 3600 & 0.466781 \\
\hline 148 & 767917.5 & 3382250 & 397.841153 & 76.73541 & 22.38462 & 3000 & 0.23885 \\
\hline 149 & 771388.5 & 3379013 & 532.447762 & 170.2393 & 15.96002 & 3000 & 0.23885 \\
\hline 150 & 764768.2 & 3382308 & 797.047751 & 356.3907 & 26.4348 & 1500 & 0.23885 \\
\hline 151 & 766830.7 & 3382907 & 496.971561 & 90.64248 & 2.683373 & 4788 & 0.23885 \\
\hline 152 & 766624.1 & 3384025 & 1633.7607 & 430.1058 & 22.09477 & 3000 & 0.23885 \\
\hline 153 & 771828.7 & 3380182 & 1691.94165 & 147.7053 & 126.836 & 2800 & 0.23885 \\
\hline 154 & 769526.3 & 3372503 & 301.88846 & 209.1813 & 54.37483 & 4200 & 0.23885 \\
\hline 155 & 771259.9 & 3378525 & 404.996776 & 504.3818 & 8.675441 & 4288 & 0.504218 \\
\hline 156 & 767737.1 & 3376683 & 1125.56596 & 8.02602 & 97.72225 & 3600 & 0.23885 \\
\hline 157 & 766168.3 & 3377005 & 777.989676 & 356.2934 & 30.45312 & 4200 & 0.23885 \\
\hline 158 & 765471.6 & 3383238 & 877.749406 & 306.3903 & 302.9974 & 3600 & 0.466781 \\
\hline 159 & 766495.1 & 3382173 & 497.220537 & 111.1262 & 23.34285 & 10000 & 0.493429 \\
\hline 160 & 770545.6 & 3377024 & 211.218886 & 249.4324 & 69.96066 & 3000 & 0.23885 \\
\hline 161 & 770841.3 & 3377660 & 573.922857 & 310.9575 & 167.3045 & 3300 & 0.466781 \\
\hline
\end{tabular}




\begin{tabular}{|l|l|l|l|l|l|l|l|}
162 & 770878.1 & 3379797 & 1045.68614 & 76.63392 & 20.82552 & 10000 & 0.493429 \\
\hline 163 & 766121.3 & 3377673 & 770.704108 & 68.85946 & 255.0609 & 3500 & 0.466781 \\
\hline 164 & 765022.5 & 3382557 & 573.760652 & 356.3907 & 39.7556 & 2500 & 0.23885 \\
\hline 165 & 770317.6 & 3379241 & 779.310302 & 451.273 & 0 & 2806 & 0.23885 \\
\hline 166 & 767531.7 & 3381152 & 954.563959 & 215.4371 & 79.52068 & 3600 & 0.23885 \\
\hline 167 & 765860.9 & 3377367 & 663.042967 & 383.8598 & 29.52934 & 2500 & 0.23885 \\
\hline 168 & 767169.9 & 3376545 & 920.927656 & 101.8338 & 251.6893 & 2400 & 0.466781 \\
\hline 169 & 770866.3 & 3379721 & 970.67985 & 76.63392 & 20.26707 & 5400 & 0.493429 \\
\hline 170 & 770192.7 & 3378807 & 730.746978 & 451.273 & 251.5662 & 4800 & 0.466781 \\
\hline 171 & 769011.9 & 3377187 & 276.982658 & 604.9103 & 59.7058 & 2400 & 0.504218 \\
\hline 172 & 768681.8 & 3379994 & 904.814806 & 42.87929 & 45.70938 & 5000 & 0.493429 \\
\hline 173 & 767944.9 & 3382322 & 324.674206 & 76.73541 & 25.44015 & 4000 & 0.23885 \\
\hline
\end{tabular}

Table 3. Intermediate stage

\begin{tabular}{|c|c|c|c|c|c|c|c|}
\hline Code & Longtitude(x) & Latitude(y) & $\begin{array}{c}\text { Distance } \\
\text { to petrol } \\
\text { station }\end{array}$ & $\begin{array}{l}\text { Distance } \\
\text { between } \\
\text { schools }\end{array}$ & $\begin{array}{c}\text { Distance } \\
\text { to main } \\
\text { street }\end{array}$ & $\begin{array}{c}\text { Area of } \\
\text { school }\end{array}$ & $\begin{array}{l}\text { Result of } \\
\text { evaluation }\end{array}$ \\
\hline 1 & 771179.8 & 3380377 & 1472.388 & 77.74655 & 34.01862 & 3600 & 0.23885 \\
\hline 2 & 768595.7 & 3377670 & 908.7294 & 996.8908 & 109.0726 & 2500 & 0.739891 \\
\hline 3 & 770926.1 & 3376523 & 598.6874 & 579.2121 & 164.9454 & 2856 & 0.466781 \\
\hline 4 & 769936.6 & 3374953 & 641.3239 & 1268.32 & 201.0006 & 3000 & 0.739891 \\
\hline 5 & 765445.1 & 3382345 & 119.6475 & 113.0459 & 43.04097 & 3000 & 0.23885 \\
\hline 6 & 770349.4 & 3376577 & 650.684 & 491.4258 & 86.98887 & 3600 & 0.23885 \\
\hline 7 & 771120.1 & 3380327 & 1446.938 & 77.74655 & 25.67436 & 3600 & 0.23885 \\
\hline 8 & 772260.8 & 3378717 & 1336.93 & 892.4189 & 23.82111 & 2800 & 0.504218 \\
\hline 9 & 767609.4 & 3375839 & 481.8633 & 605.0141 & 242.4124 & 2400 & 0.466781 \\
\hline 10 & 770012.8 & 3376219 & 669.0589 & 491.4258 & 149.6987 & 3600 & 0.466781 \\
\hline 11 & 768916.8 & 3382988 & 948.1706 & 1084.232 & 201.9796 & 8000 & 0.965179 \\
\hline 12 & 765220.6 & 3383061 & 775.6328 & 644.0954 & 127.3429 & 5400 & 0.466781 \\
\hline 13 & 771441.3 & 3379792 & 1161.614 & 624.0422 & 8.322519 & 3812 & 0.23885 \\
\hline 14 & 766406.7 & 3383630 & 1317.803 & 540.755 & 5.696093 & 6000 & 0.23885 \\
\hline 15 & 768805.6 & 3380445 & 1278.258 & 119.1641 & 25.62654 & 4200 & 0.23885 \\
\hline 16 & 766552.9 & 3382663 & 445.9016 & 547.0499 & 24.14857 & 3600 & 0.23885 \\
\hline 17 & 771482.5 & 3379154 & 687.7809 & 639.6576 & 183.3153 & 2200 & 0.466781 \\
\hline 18 & 767647.3 & 3378435 & 568.5256 & 552.8934 & 38.81487 & 4200 & 0.23885 \\
\hline 19 & 766804.1 & 3383149 & 739.2556 & 547.0499 & 40.47924 & 2500 & 0.23885 \\
\hline 20 & 768542 & 3379154 & 494.4023 & 970.7324 & 142.8213 & 2400 & 0.739891 \\
\hline 21 & 768923 & 3380424 & 1190.974 & 119.1641 & 16.61025 & 2600 & 0.23885 \\
\hline 22 & 769213.1 & 3378452 & 543.7643 & 744.5486 & 116.4297 & 6000 & 0.466781 \\
\hline 23 & 767864.6 & 3383249 & 584.8784 & 344.5741 & 45.56607 & 8000 & 0.493429 \\
\hline 24 & 764224 & 3381705 & 836.6288 & 1044.591 & 29.19837 & 2400 & 0.504218 \\
\hline 25 & 765243.3 & 3381934 & 537.0382 & 458.632 & 79.79073 & 3000 & 0.23885 \\
\hline 26 & 769995 & 3377909 & 1107.712 & 221.4738 & 51.92993 & 2400 & 0.23885 \\
\hline 27 & 769782.9 & 3377973 & 1006.311 & 221.4738 & 36.44754 & 5000 & 0.23885 \\
\hline
\end{tabular}




\begin{tabular}{|r|c|r|r|r|r|r|r|}
\hline Code & Longtitude(x) & Latitude(y) & \multicolumn{1}{|c|}{$\begin{array}{c}\text { Distance } \\
\text { to petrol } \\
\text { station }\end{array}$} & $\begin{array}{c}\text { Distance } \\
\text { between } \\
\text { schools }\end{array}$ & $\begin{array}{c}\text { Distance } \\
\text { to main } \\
\text { street }\end{array}$ & $\begin{array}{c}\text { Area of } \\
\text { school }\end{array}$ & $\begin{array}{c}\text { Result of } \\
\text { evaluation }\end{array}$ \\
\cline { 2 - 7 } 28 & 769083.6 & 3380552 & 986.2869 & 205.179 & 52.72162 & 3600 & 0.23885 \\
\hline 29 & 769189.8 & 3373152 & 1009.359 & 454.061 & 76.99593 & 2400 & 0.23885 \\
\hline 30 & 768407.7 & 3373005 & 353.6052 & 795.7303 & 45.82983 & 4200 & 0.504218 \\
\hline 31 & 767117.7 & 3377799 & 1053.099 & 345.6545 & 29.64823 & 2450 & 0.23885 \\
\hline 32 & 765875.4 & 3383530 & 1205.618 & 540.755 & 202.9406 & 2500 & 0.466781 \\
\hline 33 & 765377.8 & 3382436 & 198.5748 & 113.0459 & 40.34916 & 3600 & 0.23885 \\
\hline 34 & 769783.7 & 3380418 & 696.8399 & 712.7883 & 30.27287 & 3600 & 0.23885 \\
\hline 35 & 767535.1 & 3383149 & 653.4616 & 344.5741 & 300.7043 & 2400 & 0.466781 \\
\hline 36 & 767325.1 & 3378884 & 83.97073 & 552.8934 & 16.14542 & 3600 & 0.025651 \\
\hline 37 & 768209.7 & 3375914 & 368.5426 & 605.0141 & 74.62779 & 5600 & 0.23885 \\
\hline 38 & 766791.7 & 3381660 & 621.0626 & 1030.855 & 160.7185 & 4200 & 0.739891 \\
\hline 39 & 769609.6 & 3372979 & 671.5084 & 454.061 & 105.4622 & 2800 & 0.466781 \\
\hline 40 & 766791.9 & 3377914 & 1036.616 & 345.6545 & 33.63162 & 3600 & 0.23885 \\
\hline 41 & 766426.7 & 3377793 & 1064.963 & 384.7833 & 239.2825 & 2400 & 0.466781 \\
\hline
\end{tabular}

Table 4. High stage

\begin{tabular}{|c|c|c|c|c|c|c|c|}
\hline code & Longtitude(x) & Latitude(y) & $\begin{array}{c}\text { Distance } \\
\text { to petrol } \\
\text { station }\end{array}$ & $\begin{array}{l}\text { Distance } \\
\text { between } \\
\text { schools }\end{array}$ & $\begin{array}{c}\text { Distance to } \\
\text { main } \\
\text { street }\end{array}$ & $\begin{array}{c}\text { Area of } \\
\text { school }\end{array}$ & $\begin{array}{l}\text { Result of } \\
\text { evaluation }\end{array}$ \\
\hline 1 & 771074.9 & 3378355 & 424.2267 & 280.2251 & 21.78511 & 3600 & 0.23885 \\
\hline 2 & 766093.7 & 3383468 & 1223.688 & 956.0143 & 1.313818 & 6000 & 0.23885 \\
\hline 3 & 765521.6 & 3378592 & 804.3084 & 228.0426 & 26.9894 & 3900 & 0.23885 \\
\hline 4 & 768197.9 & 3377722 & 1250.74 & 157.6417 & 155.1007 & 2400 & 0.466781 \\
\hline 5 & 768247 & 3377871 & 1301.976 & 157.6417 & 45.50954 & 4800 & 0.23885 \\
\hline 6 & 770348.1 & 3374465 & 1239.342 & 2082.501 & 117.053 & 3600 & 0.739891 \\
\hline 7 & 769260 & 3372053 & 580.634 & 2037.09 & 70.85331 & 2400 & 0.504218 \\
\hline 8 & 767971.6 & 3383206 & 523.1631 & 743.5291 & 28.09357 & 2600 & 0.23885 \\
\hline 9 & 767902.8 & 3382248 & 401.4565 & 960.3897 & 35.16001 & 3000 & 0.23885 \\
\hline 10 & 767140.8 & 3376604 & 915.3015 & 584.2045 & 229.018 & 3600 & 0.466781 \\
\hline 11 & 770542.7 & 3377827 & 760.9575 & 691.1527 & 34.37308 & 4500 & 0.23885 \\
\hline 12 & 769714.1 & 3377600 & 744.7903 & 171.162 & 102.5618 & 3980 & 0.466781 \\
\hline 13 & 768192 & 3380575 & 1258.433 & 961.8295 & 92.17419 & 4500 & 0.23885 \\
\hline 14 & 769151.5 & 3380509 & 957.1432 & 961.8295 & 106.6277 & 5400 & 0.466781 \\
\hline 15 & 767214.4 & 3377865 & 978.8543 & 830.1353 & 13.72746 & 10000 & 0.493429 \\
\hline 16 & 770905.9 & 3379578 & 826.3095 & 865.5028 & 15.48863 & 3000 & 0.23885 \\
\hline 17 & 766858.5 & 3377115 & 1038.404 & 584.2045 & 221.358 & 3600 & 0.466781 \\
\hline 18 & 766425.1 & 3374080 & 1334.037 & 687.1179 & 30.16373 & 2500 & 0.23885 \\
\hline 19 & 767961.2 & 3373622 & 461.8298 & 1044.975 & 143.6621 & 10000 & 0.712045 \\
\hline 20 & 766351.1 & 3382418 & 575.6387 & 214.0392 & 27.64897 & 3600 & 0.23885 \\
\hline 21 & 768123.4 & 3376361 & 772.1655 & 353.4765 & 29.56481 & 5400 & 0.23885 \\
\hline 22 & 766927.6 & 3383000 & 580.755 & 591.1653 & 0 & 10000 & 0.493429 \\
\hline
\end{tabular}




\begin{tabular}{|c|c|c|c|c|c|c|c|}
\hline code & Longtitude(x) & Latitude(y) & $\begin{array}{c}\text { Distance } \\
\text { to petrol } \\
\text { station }\end{array}$ & $\begin{array}{c}\text { Distance } \\
\text { between } \\
\text { schools }\end{array}$ & $\begin{array}{c}\text { Distance to } \\
\text { main } \\
\text { street }\end{array}$ & $\begin{array}{c}\text { Area of } \\
\text { school }\end{array}$ & $\begin{array}{c}\text { Result of } \\
\text { evaluation }\end{array}$ \\
\hline 23 & 767748.2 & 3378544 & 579.5042 & 837.5917 & 89.54303 & 4800 & 0.23885 \\
\hline 24 & 772746.8 & 3379106 & 1856.612 & 475.4162 & 60.86107 & 2870 & 0.23885 \\
\hline 25 & 771144.8 & 3378627 & 253.51 & 280.2251 & 96.30081 & 2870 & 0.23885 \\
\hline 26 & 765649.9 & 3378780 & 1018.392 & 228.0426 & 6.402242 & 4200 & 0.23885 \\
\hline 27 & 771737.8 & 3379339 & 1003.274 & 208.4642 & 24.88177 & 4500 & 0.23885 \\
\hline 28 & 772410.7 & 3378770 & 1486.435 & 71.14989 & 95.88665 & 4000 & 0.23885 \\
\hline 29 & 772347.3 & 3378738 & 1423.031 & 71.14989 & 27.55739 & 4000 & 0.23885 \\
\hline 30 & 772347.3 & 3379494 & 1604.654 & 455.2984 & 25.88572 & 4500 & 0.23885 \\
\hline 31 & 772509.1 & 3380053 & 2050.38 & 582.2799 & 25.491 & 3500 & 0.23885 \\
\hline 32 & 771892.3 & 3379479 & 1210.672 & 208.4642 & 93.39019 & 2640 & 0.23885 \\
\hline 33 & 769005.3 & 3382679 & 987.0888 & 1160.341 & 169.1831 & 4500 & 0.466781 \\
\hline 34 & 767914 & 3383948 & 1266.672 & 743.5291 & 4.375418 & 4000 & 0.23885 \\
\hline 35 & 767150 & 3383548 & 1150.378 & 591.1653 & 112.9309 & 8000 & 0.466781 \\
\hline 36 & 767953.2 & 3376051 & 461.656 & 353.4765 & 56.2752 & 3600 & 0.23885 \\
\hline 37 & 766567.3 & 3376398 & 310.0398 & 609.1675 & 6.986935 & 2500 & 0.23885 \\
\hline 38 & 767099.2 & 3374213 & 682.3154 & 687.1179 & 71.10298 & 2500 & 0.23885 \\
\hline 39 & 766503.5 & 3382267 & 449.8211 & 214.0392 & 26.10098 & 6000 & 0.23885 \\
\hline 40 & 773449.1 & 3377341 & 2715.617 & 1766.657 & 17.23659 & 7500 & 0.504218 \\
\hline 41 & 769869 & 3377673 & 902.655 & 171.162 & 59.75791 & 3600 & 0.23885 \\
\hline 42 & 771993.7 & 3375742 & 1840.756 & 2082.501 & 47.14767 & 2500 & 0.504218 \\
\hline
\end{tabular}

